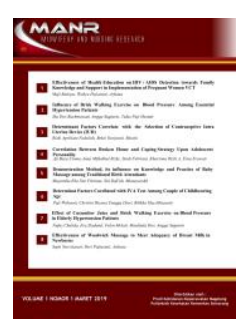

MIDWIFERY AND NURSING RESEARCH (MANR) JOURNAL Volume 3 Issue 2 Year 2021

http://ejournal.poltekkes-smg.ac.id/ojs/index.php/MANR p-ISSN: 2685-2020; e-ISSN: 2685-2012

\title{
Baby Yoga Improves Weight of Baby 3-12 Month
}

\author{
Silvia Ari Agustina1), Reni Merta Kusuma²)
}

Email : silviaari889@gmail.com

\begin{abstract}
Background: Emotional closeness is very important for physical growth, emotions and intelligence of babies. The benefit of doing Yoga is to create physical and mental health as well as creating a balance. Research on the effect of baby yoga on infant growth is still limited. The purpose of this study was to determine the effect of yoga on the baby's body weight and length

Methods: The research method used is quasi-experimental design with the Pre-Post-test Control Group Design method. This study involved 36 samples of infants who had nutritional problems. Which were divided into 2 groups with 18 samples each. The treatment was carried out for 2 months, and 4 treatments were carried out monthly. The statistical test used is paired sample T-Test dan independent T-Test.

Results: The statistical test result of paired sample T-Test for Baby Yoga treatment significantly affected the baby's weight and body length with $p$ value $=0.000$. The results of the Independent T-Test, the difference in body weight between the baby yoga group with growth and development stimulation was known to be $p<0.05(p=0.012)$, there was a difference in weight gain between baby yoga and growth and development stimulation. However, for differences in body length difference test, showing a value of $p>$ $0.05(p=0.150)$, the results in body weight and body length difference between the treatment of baby yoga with growth and growth stimulation showed that there was no significant difference between the provision of baby yoga with growth and growth stimulation to increase body length.

Conclusion: There is a weight difference between baby yoga treatment and growth stimulation, but no significant difference for body length.
\end{abstract}

Keyword: Baby Yoga; Weight

1,2Department of Midwifery, Jenderal Achmad Yani University Yogyakarta, Indonesia

Jl. Brawijaya Ringroad Barat Ambarketawang, Gamping, Sleman, Yogyakarta, Indonesia

Received: September 27, 2021; Revised: September 28, 2021; Accepted: September 30, 2021

Background. Yoga is not only beneficial for adults, but also usefull for babies like yoga can aid digestion and alleviate colic, help to strengthen tiny limbs, improve sleep patterns, and enhance their ability to interact with their mother and other people (MacDonald, 2013).

Parents play an important role and a great responsibility for the growth and development of infants. Every living thing must experience growth and development. Growth changes include physical changes, such as gaining weight and height, and developmental changes such as thinking, emotions, and behavior (Jafar, 2015). The period of infancy to children under 5 years is the most important time in the process of forming and developing integrated personality (Hardjadinata, 2011).

The results of the 2016 National Nutrition Monitoring in Indonesia as many as $3.4 \%$ of children under five have malnutrition status and $14.4 \%$ of children under five have nutritional status, while in Yogyakarta there are 2.1\% experiencing malnutrition and $13.8 \%$ experiencing undernutrition (Kemenkes, 2017). In 2016 the most cases of malnutrition were in the city of Yogyakarta, namely 96 people, both in Bantul Regency 43 people, then Sleman, Kulonprogo, and Gunungkidul (Dinas Kesehatan, 2017).

Delay in growth and development is a serious problem for developed countries and developing countries in the world. As one of the developing countries, in recent years the public awareness has begun to emerge to pay more attention to the growth and development of their children physically, mentally/ psychologically and socially. Various attempts by parents to improve the health level of their babies, began routinely taking part in Integrated Healthcare Center, giving exclusive breastfeeding, and several other methods that 
have begun to become more intense lately such as yoga for infants (Hardjadinata, 2011).

Yoga is not only done by adults but can be done by children and even infants. One benefit of a baby doing yoga is to optimize the baby's growth and development, both physically and mentally (Octama, 2019). Basically, yoga is a physical exercise involving the baby holistically, both physically and psychologically (AyahBunda, 2019). Yoga movements given to babies are much gentler and slower than traditional yoga or adult yoga in general. The movements in baby yoga are adapted to the baby's physical condition and adapted to the baby's stages of growth and development (Agustina SA, 2020). The positive influence of touch on the process of growth and development of infants has long been known to humans. But scientific research on this matter has not been done much (Roesli, 2016).

Increasingly, there are high growth and development problems for infants and toddlers, and it is very important to conduct research related to the prevention of these problems. One alternative that has not been much studied is the effect of baby yoga on infant growth (weight and body length). The purpose of this study was to determine the effect of yoga on the baby's body weight and length.

Methods. This study uses a quasiexperimental design (quasi experiment) with the Pre-Post-test Control Group Design method. The location of the study was conducted in the area of the Village of Bener, Tegalrejo, Yogyakarta City. The time of the study was conducted from May 2019 until September 2019.

The population in this study were infants aged 3-12 months who experienced nutritional problems such as BGM, BGT, stunting, and unstable body weight within one month. As many as 36 samples were chosen with the purposive sampling technique. Samples were taken by taking into account exclusion criteria such as babies with a history of heart disease, Diabetes mellitus, and physical abnormalities. Initial data collection techniques by measuring body weight and body length then the samples were divided into 2 groups, the first group was treated with baby yoga, and second groups as a control was given developmental stimulation. The treatment was carried out for 2 months, and 4 treatments were carried out monthly. The final step was checking body weight and length for the final data.
The instruments used in this study include scales and measuring devices for body length to determine the growth of the baby. The statistical test used was the paired sample ttest and the difference test. Previously, the normality and variance test was carried out using the Shapiro Wilk test with normal and homogeneous results.

Result and Discussion. Body weight is a benchmark to determine a child's health (Widyastuti, 2008). According to (Engel, 2009), weight gain and weight must be considered in infants, therefore weight assessment is an important first step in providing preventive health care and services.

\section{Effects of yoga on baby's weight and body length}

After giving yoga treatment for 2 months, there was an increase for the terms, using first and second groups. However, in Group II, there were $22.2 \%$ of babies experienced weight decrease after given the growth and stimulation treatments for 2 months. For body length, both groups experienced a $100 \%$ increase after given growth stimulation. Yoga is a sport that emphasizes breathing techniques to improve body freshness, fitness, and health. The movements of baby yoga are very simple, fun, and soothing for babies. For babies, yoga can provide many benefits, such as increasing the baby's body power as yoga stretching movements can reduce abdominal pain, bloating, colic and constipation and improve the function of the digestive system in order to maintain the baby's body weight and nutrient intake can be absorbed optimally (Beyond, 2019; Hardjadinata, 2011).

The main benefit of baby yoga is that all the baby's body systems are stimulated, including the digestive system and nerves so that the baby's appetite increases, as well as the baby's weight increases (Fauziah IN, 2015).

Pre-test and post-test values were used to determine the effectiveness of each treatment which was calculated using a paired sample ttest parametric statistical test, with the following results:

Table 1. Results of Paired Sample T. Test Analysis

\begin{tabular}{lc}
\hline & P value \\
\hline BB Pre-Post Baby Yoga & 0,000 \\
BB Pre-Post Growth stimulation & 0,005 \\
PB Pre-Post Baby Yoga & 0,000 \\
PB Pre-Post Growth stimulation & 0,000 \\
\hline
\end{tabular}


The results of the analysis to determine the effect of giving baby yoga significantly on weight gain, with a $p$ value less than 0.01 . Likewise, with the group that was given growth and development stimulation, the results of the pre-test and post-test analysis of giving baby yoga treatment with a $p$ value of $0.005, P$ $<0.05$, so that Ho was rejected, meaning that there was a statistically significant effect. Not only weight, the results of statistical tests have also been proven to influence the increase in body length

These results are in accordance with the results of research conducted by Mahanani (2017), that infant physical exercise showed an increase in infant weight, this is because infant gymnastics can increase infant muscle relaxation and bring babies to relax by building the nervous system, give a fit effect on babies and stimulate the growth and development of the baby, therefore the baby is not stressed and increased his appetites (Mahanani S, 2017).

According to Ardiana's theory. D (2013) cited by Rokayah (2018), said that babies who receive stimulation through touch will affect the tone of the vagus nerve (10th brain nerve), so that it can stimulate increased levels of gastrin and insulin absorption enzymes that can increase body weight (Rokayah D, 2018).

In addition, through yoga, all systems of the baby's body are stimulated, including the digestive and nervous systems. Baby yoga increases the baby's appetite and helps the baby to overcome colds, constipation, and colic in babies. Because the baby's appetite increases, so it can increase the baby's weight (Agustina SA, 2020).

Yoga movements have many benefits in terms of health. One of them is able to stimulate the epidermal, digestive tract, spleen, heart, and respiratory system. In addition, it is also believed to help cleanse the toxins in the body and balance the endocrine system (Hardjadinata, 2011).

\section{Differences in weight and length of the baby in the group that was intervened with the control group.}

The results of the analysis test using the Levene test probability value is more than 0.05 , in conclusion, that it has the same variance, thus the t-test difference analysis used the assumption of equal variance assumed with a $\mathrm{p}$-value of 0.150 , so it can be concluded that Ho is accepted. However, there is no significant difference between giving baby yoga with growth and development stimulation to increase body length. In fact, it is clear from the mean value in absolute terms, that between the two treatments the mean value is not much different from 2.21. As for the effect on body weight, it is known that the $p$ value $<0.05$, meaning that there is a difference in the effect between giving baby yoga treatment and stimulation of growth and development.

Table 2. Results of Independent T. Test Differences

\begin{tabular}{llc}
\hline & Mean & P value \\
\hline BB Baby Yoga & 9,64 & 0,012 \\
BB Growth stimulation & 8,47 & \\
PB Baby Yoga & 73,82 & 0,150 \\
PB Growth stimulation & 71,61 & \\
\hline
\end{tabular}

Statistically, there was no significant difference between infants who were given yoga treatment and those who were stimulated with growth and development stimulation. Babies both experience an increase in body length. Growth is a change in the size, number, size, or dimensions of the level of an organ's cells, or individuals that can be measured by weight (grams, pounds, kilograms), length $(\mathrm{cm}$, meters), bone age, and metabolic balance (calcium retention and body nitrogen) (Adriyana, 2013).

Baby yoga can be done from the age of 3 months. The movements of most or all of the movements used in baby yoga have been adjusted for the baby, so the movements are not very strong and not dangerous at all (Beyond, 2019). Yoga movements can be useful for babies if it is done safely by parents and accompanied by experts_(Rettner, 2012).

Baby yoga is proven to be more effective in increasing the bonding attachment between mother and baby (Agustina SA, 2019). According to Hardjadinata (2011), it is not easy to do yoga without expert assistance, so if the mother wants to do it perfectly, you should seek advice from a yoga therapist. Especially for babies, yoga movements must be done carefully so as not to make her body sick (Hardjadinata, 2011).

Conclusion and Suggestions. Baby yoga if done correctly will provide many positive benefits, especially for babies. Baby yoga has a positive influence on a baby's weight and length. The results in body weight and body length difference between the treatment of 
baby yoga with growth and growth stimulation showed that there was no significant difference between the provision of baby yoga with growth and growth stimulation to increase body length.

Suggestions for further research are adding the number of research samples and improving research methods using mixed methodology. Suggestions for health workers are baby yoga can be used as an alternative to increase baby's weight. In fact, for the growth of babies, both weight and body length, there are many factors that influence, so it is possible to influence the results of this study. For further research in order to increase the number of samples and control other factors that affect the growth of babies

Acknowledgements. The authors would like to thank 1) the Ministry of Research, Technology and Higher Education of the Republic of Indonesia for providing full funding for this research. 2) Institute for Research and Community Service Jenderal Achmad Yani Yogyakarta University who gave full support to the completion of this research.

\section{References}

Adriyana, D., (2013). Growth \& Development \& Play Therapy in Children. Jakarta: Salemba Medika.

Agustina SA, K. R., (2019). Baby Yoga's Effect of Bounding Attachment. Surakarta, Proceeding"1'st International Conference Health, Science, and Technology (ICOHETECH) Universitas Duta Bangsa Surakarta, pp. 4-6.

Agustina SA, K. R., (2020). Baby Yoga Stimulation of Growth and Development of 3-12 Months. Purwodadi: CV Sarnu Untung.

AyahBunda, (2019). Yoga for Baby's. Ayahbunda Magazine Article, pp. https://www.ayahbunda.co.id/bayi-gizikesehatan/yoga-untuk-bayi.

Beyond, E. a., (2019). What is Baby Yoga. Company England: Sapling Digital Ltd.
Dinas Kesehatan, D., (2017). Profil Kesehatan Tahun 2016. Yogyakarta: Dinas Kesehatan Daerah Istimewa Yogyakarta.

Engel, J., (2009). Pediatric studies (Esty, W, Terj.). Jakarta: EGC.

Fauziah IN, D. L. A. Y., (2015). Development Model of Mother's Behavior in Prevention of Malnutrition in Toddlers. Jurnal Ners, pp. 195-207.

Hardjadinata, Y., (2011). Yoga For Baby. Jakarta: Dian Rakyat.

Jafar, N., (2015). Growth and Development. Makasar: Nutrition Science Study Program, Faculty of Public Health, Hasanuddin University Makassar.

Kemenkes, R., (2017). Guidelines for the Implementation of Stimulation, Detection and Early Intervention of Child Development at the Primary Health Service Level. Jakarta: Kementerian Kesehatan Republik Indonesia.

MacDonald, C., (2013). Mother and baby yoga is good for you. Pract Midwife, 16(5), pp. 14-18.

Mahanani S, M. S., (2017). Weight Gain of Infants Age 6-12 Months Through Baby Gymnastics in the Work Area of the Pesantren 1 Public Health Center, Kediri City. Stikes Journal. ISSN 2085-0921, 10(2), pp. 89-160.

Octama, C., (2019). Can I Do Yoga With A Baby?. Orami Parenting Article, pp. https://parenting.orami.co.id/magazine/bol ehkah-melakukan-yoga-bersama-bayi/.

Rettner, R., (2012). Yoga for Babies. Is it save?. Live Science Article, pp. https://www.livescience.com/18688-.

Roesli, U., (2016). Baby Massage Guidelines Revised Edition. Jakarta: Trubus Agriwidy.

Rokayah D, N. L., (2018). The Effectiveness of Baby Massage on Growth and Development in Infants Age 5-6 Months in Rangkasbitung Barat Village in 2017. Jurnal Medikes, 5(2).

Widyastuti, D. \&. W. R., (2008). Child Development Guide 0-1 Years. (ed 8). Jakarta: Puspa Swara. 